\title{
The Obstacles to Reform: China Modernizes Its University Libraries
}

\section{Henrietta Lo}

Based on her seven-month research on university libraries in China during 1983 and 1985, the author discusses the problems confronting Chinese libraries in their courageous leap from medieval book-preservation warehouses to high-tech information centers. The paper argues that the problems are mainly caused by China's political and social structures and economic conditions. The discussion emphasizes user services, a new development mandated for university libraries by China's National Education Commission and an area where the author dares to claim some expertise.

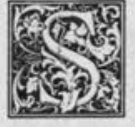

ince 1979 a noticeable number of Western information workers and scholars have visited and reported on Chinese libraries. Among approximately twenty substantial articles, less than half offer insights on the obstacles confronting Chinese libraries.

One of Chen Ching-chih's papers published in 1980 discusses the problems in China's program of educating and training professional information personnel. ${ }^{1}$ K. P. Broadbent's 1981 report explains why the Chinese written language poses a formidable obstacle to modern information processing in China. It further comments that China's shortage of paper, foreign monetary exchange restrictions, "fragmentation of effort and lack of coordination" among participants, and outmoded telephone system have multiplied the difficulties. ${ }^{2}$

In her 1981 paper, Ting Lee-hsia describes the serious problems faced by Chinese catalogers due to the coexistence of several classification schemes within individual libraries. ${ }^{3}$ James Chan's 1986 article makes it clear why Chinese university li- braries have such great difficulty obtaining new foreign publications in a timely manner and informing themselves of current publications. ${ }^{4}$ A 1986 report by Maureen Pastine on the visit to Chinese libraries by a team of American librarians comments on the inadequacy of reference services. ${ }^{5}$

This paper attempts to define the unique characteristics of the obstacles challenging both Chinese university libraries and their users. An examination of the development of librarianship in modern China is in order.

China is a latecomer in the founding of libraries accessible to the general public. The first provincial public library was set up in 1903 by an American, Elizabeth Wood, who arrived there in $1900 .^{6}$ She also founded the first library school in China, Wen-hua, in 1920, and helped send some of the school's graduates to the U.S. for further studies in librarianship. Hence China's modern librarianship had a very strong American orientation: Dewey was widely used after 1904 and even the LC classification system was adapted by a few university libraries. The 
founding of the People's Republic of China in 1949 brought about some radical changes. In that year a second library school was established at Beijing University, China's top-ranking institution of higher education, terminating Wen-hua's monopoly as the provider of trained librarians. In 1953 Wen-hua lost its independent status and was incorporated into Wuhan University. No other library schools were established until 1977. As a result, of China's 140,000 information workers, only 2 percent had professional training.

Generally speaking, the first half of the 1950 s saw a rapid development of Chinese libraries. The Chinese leadership decided to model the country after the Soviet Union. As a measure to provide mass education, particularly to factory workers and rural peasants, many public libraries were set up. To support scientific research, libraries or information centers were created for the many newly established institutes. The libraries were governed by various exclusive state agencies; for example, the library of the Beijing Industrial College might be responsible to the Ministry of Defense while that of the Beijing Industrial University would answer to the National Education Commission. Public libraries, including China's national library, would be under the control of the Ministry of Culture. Unfortunately, no attempt was made to coordinate the different types of libraries to form a network of information. Neither was there any direction from the state for setting up policies or standards for libraries. Today, even though efforts are being made to regulate the different types of libraries, this lack of coordination and cooperation has caused confusion and inefficiency among Chinese libraries and a great deal of frustration to the library user. A good illustration of this is provided by the firsthand accounts of six American historianssophisticated library users-on gaining access to Chinese libraries and archives during 1982-84.

Another undesirable Soviet transplant in the early 1950 s was the separation of the small number of information workers into two distinctive groups-librarians and in- formation scientists. Even the curricula in library schools split into two mutually exclusive divisions, resulting in unnecessary duplication of efforts and depletion of resources. ${ }^{8}$ The establishment of the Institute of Scientific and Technical Information of China under the Academy of Science in 1958 widened the rift. ${ }^{9}$ Today the two leading Chinese library schools are trying to integrate the divisions into one unit again, but it will take a long time to eradicate the common belief among most information workers that librarians, who have been trained in the social sciences, are passive keepers of books while information officers, who have been trained in science and technology, are active providers of information. ${ }^{10}$

The role of the academic librarian in actively supporting research was further diminished by the establishment of information rooms in individual academic departments, again a Soviet legacy. These rooms, which exist to serve only their respective professors and graduate students, are held responsible to the academic units, although the bulk of their collections is obtained from the university library. Naturally, this configuration has added to the unnecessary duplication of materials and to fragmentation of the university libraries' scanty resources. Very often the items housed in the information rooms cannot be located, even though they appear in the university library cata$\log$.

The patriotic zeal of the period stirred up criticism of the existing systems used to organize knowledge in libraries: Dewey must yield its predominance. In 1954 a classification scheme, aimed mainly at university libraries, was compiled and published by the People's University, a key institution originally founded by the state to provide higher learning to topranking cadres. It was followed in 1956 by the classification scheme of the Academy of Science, designed for libraries of the various state research institutes. The Chinese Library Classification was published in 1974 , and most libraries were required to organize their collections according to this "politically correct" system. Thereafter, not only were information workers and re- 
sources fragmented, but so was the classification of library collections. The latter fragmentation is most damaging because the public catalog in Chinese libraries is basically a classified one. ${ }^{11}$ When a closedstack collection is classified by several schemes, which is the norm for most Chinese university libraries, it increases difficulty for the user gaining access through the card catalog and for the library worker retrieving the requested items from various locations.

When the Soviet Union withdrew its technicians in the late 1950s, China felt betrayed. That caused the strengthening of the traditional peasant mentality of selfreliance. The concept of "small but complete" ' became pervasive in almost all undertakings; among libraries, this led to less and less coordination and cooperation. In an age of information explosion, this behavior has worked against China's efforts to modernize its libraries.

The Great Leap Forward movement (1957-61) appeared to advance library ser-

\section{"The political movement that is most devastating to Chinese culture in general and Chinese university li- braries in particular is the ironi- cally named Cultural Revolution (1966-76).'"}

vices through its goal of delivering books to the populace, particularly the poor in rural areas. Unfortunately, like the other innovative ventures of this period, e.g., backyard steel furnaces, the true picture is very different. Libraries were decimated: many valuable books were never returned. Library workers became adverse to open stacks and adhered more strongly to the feudal concept of preserving the collection for posterity. Also, the Maoist approach placed politics at the top and expertise at the bottom of the social hierarchy. Professional library workers were put under the command of "politically correct" persons, who might be illiterates, and opened the library mainly to "workers, soldiers and peasants." Rules, regulations, and procedures were abandoned, and libraries sank into disarray.

The political movement that is most devastating to Chinese culture in general and Chinese university libraries in particular is the ironically named Cultural Revolution (1966-76). During this period many library collections, considered the legacy of the reactionary past or the products of the poisonous bourgeoisie, were destroyed. Librarians, looked upon as the servants of feudalism and capitalism, were sent to reform schools or work farms in the barren areas of the country. Libraries were radically renovated: numerous copies of Chairman Mao's writings were acquired and, together with the writings of Marx and Lenin, became the only books made available to library users. Management was equated with reactionary suppression, and anarchy became the order of the day. Many incompetent cadres looked upon the library as a refuge and secured sinecures through the back door. This situation fostered the growing misconception that anyone could qualify as a librarian. Although the Cultural Revolution ended in 1976, the damages done to library collections, management, and personnel are too great to be remedied in a single decade. Today Chinese university libraries are fiercely fighting an uphill battle to achieve modernization.

In a 1985 user survey, the first taken by a Chinese-American librarian, the following observations were volunteered by respondents under "other comments":

1. Too few seats.

2, Need for better-trained, courteous workers at the circulation counter. ("After waiting for almost an hour, I was told that the book I need was not on the shelf, and the worker refused to go back into the stacks to get me a different title from the same subject area.")

3. Institute open stacks.

4. Card catalog difficult to use and no help available.

5. Not enough copies of useful titles.

6. Insufficient current foreign publications, particularly journals.

7. Need to improve services with automation and scientific management. ${ }^{12}$ 
Although many Chinese academic librarians are becoming aware of these problems, solutions are not readily available because of China's political, social and economic structure.

Since 1978 efforts have been made to improve all types of libraries as one support for China's "four modernizations" (of industry, agriculture, science/technology, and defense). Limited authority was conferred on the China Society of Library Science, founded in 1979, to develop libraries for the following: (1) mass education, (2) scientific and technological research, (3) dissemination of information, and (4) preservation of books. ${ }^{13}$ In regard to university libraries, extensive guidelines and standards are now available. In September 1981, when the National Education Commission convened a meeting to discuss the work of university libraries and create the National Committee on Academic Libraries, it unveiled its Regulations for College and University Libraries. The Regulations were officially issued in October 1981. These thirty regulations deal with: (1) functions and missions, (2) operations and services, (3) organization and structure, (4) personnel, and (5) budget, building, and equipment. The emphasis is on good collections, efficient services, effective management, qualified personnel, adequate budgets, study-conducive buildings, and modern equipment; catalog standardization and interlibrary cooperation are stressed. Indeed, if all the conditions specified by the Regulations were achieved, Chinese academic libraries would become highly efficient and effective information centers comparable to their counterparts in the Western world. However, the state has not made a top priority of helping university libraries to attain such conditions.

To illustrate the unique difficulties confronting Chinese university libraries and their users, consider the following scenario based upon the author's own experiences and contacts. ${ }^{14}$

Liu is a third-year computer science student in one of China's six top universities. He wants to learn about current trends in technologically advanced societies. Because the information room of the com- puter science department serves only department faculty and graduate students, he must use the university library. He goes to the social sciences reading room, where there is a small, open-stack collection of recent Chinese publications for reference purposes. He is, however, denied entry by the room attendant, who has been told to admit only students whose library cards indicate that they are social science majors. Lieu goes to the reading room section head to explain his needs but is told that because his major is computer science, he has no business in the social sciences reading room. He should go to the science and technology reading rooms to meet his needs. ${ }^{15}$

Realizing that the most pertinent information on the topic should be in Englishlanguage publications and because he can read some English, Liu decides to go to the foreign publications reading room. Again he is barred at the door. The librarian on duty, whom Liu recognizes as his senior classmate by two years, tells him that only faculty and graduates are admitted because there is already insufficient seating for qualified readers. Liu can see at a glance that the room is indeed very crowded. He is advised to go to the union card catalog to check out books from the main stack collection.

Liu is at a loss in the card catalog room. He has used only the author and title catalogs but now must use the classified cata$\log$. After reading all the instruction guides posted on the walls, he understands that of the three separate classified catalogs-Dewey, Academy of Science, and Chinese Library-he needs to use only the last two because the Dewey catalog includes only books published before 1960. After an hour, Liu still fails to find appropriate class numbers for the books he wants. He therefore approaches the catalog information desk for help. The librarian on duty, a man in his early fifties, does not seem to understand what Liu wants. He tells him to write down his request in the "queries book" and come back for the answer in a day or two. Liu asks whether the library, if it does not have what he wants, will get the book for him from another library. "We have every 
available item in this region. What we don't have won't be found in other libraries," replies the librarian.

In the meantime, Liu happens to see his cousin in the canteen. The cousin is a graduate student in library and information science and he recommends to Liu the Chinese translation of John Naisbitt's $\mathrm{Me}$ gatrends, one of the five most demanded books of the previous year. Liu returns to the library, finds the title in the card cata$\log$, and submits his book request at the circulation counter. Forty minutes later the attendant returns, stating that the book is not on the shelf. Liu suspects that the attendant, who is in his early thirties and seems to enjoy chatting with his coworkers too much to go looking for books, has not searched carefully for the title in the right place. He asks the attendant to look for it one more time. Heated arguments ensue, followed by a scuffle. Both are taken to the office of Huang, deputy library director.

\section{". . . recommends to Liu the Chinese translation of John Naisbitt's Mega- trends, one of the five most de- manded books of the previous year."}

Apparently it is not the first time that the attendant has gotten himself involved in this type of situation. After challenging Huang to remove him from his library post, he takes his leave. Huang tells Liu that he had indeed tried to transfer the attendant to another department on campus. After fully documenting why the person is unsuitable for library work, his request to have the person transferred to another area had been approved by the university personnel office. But no unit would agree to accept the person-a former Red Guard who has hardly any education beyond the fourth grade, and who strongly resents offering service to intellectuals whom he despises and envies at the same time. Because the state's policy of no unemployment practically guaran- tees him an "iron rice bowl" he gets his paycheck for merely showing up at work. It looks as if he will stay in his library post for a long while.

Huang explains that many books have not been reshelved recently because six of the stack workers have been given released time, as required by state regulations, to study for the upcoming TV university examinations. Appreciating the efforts undertaken and the frustrations endured by Liu, he offers to have the book retrieved and kept at the counter for him.

Liu then pleads for an open-stack library. Huang explains that even though that is a long-term goal, it is presently impossible unless the library building, finished only ten years ago, could be remodeled. Besides, the collection is not organized for public access-it is broken up by several classification systems, language divisions, and pre- and post-1949 publication dates. In certain areas, e.g., Cultural Revolution propaganda literature, hundreds of duplicate copies are bundled and piling up on top of the shelves. Also, there is no antitheft device to prevent irreplaceable items from disappearing.

Huang assures Liu that he is fully aware of the poor user services at the circulation counter and is considering remedying the situation by hiring some undergraduate students as part-time workers. During his recent visits to American university libraries, the part-time student workers impressed him as a very effective labor force. Liu asks if an automated circulation system would help. Huang admits that, like most other librarians, he had held the opinion that if Chinese libraries were automated, all administrative and operational problems would be solved. ${ }^{16}$ However, he now realizes that most of these problems need to be resolved before automation can take place.

Because Liu is interested in library services, Huang suggests that perhaps he would like to join the library automation unit after his graduation the following year. Liu is surprised that there is such a unit because there is no sign of automation in the library. Every sizable university library is required by the 1981 Regulations 
to set up a systems unit, replies Huang. The unit in his library, established three years ago, has nine staff members who have been investigating various library automation systems so that the library would be ready when the National Education Commission approves its purchase of a minicomputer with World Bank loans next year.

The conversation is interrupted by a staff member who wants Huang to find her a baby-sitter or get her two-year-old child admitted to the campus day-care center because her mother is returning to her brother's farm. Liu leaves the deputy director's office wondering if he wants to work in a library. Librarians are still rather low on the social scale but working in a university, particularly a prestigious one, is considered desirable. Besides, it will guarantee his rights of residence in a prosperous urban area. But why should he waste time on this question since most likely he will accept whatever work assignment is mandated for him by the state?

Liu finds Megatrends waiting for him at the circulation counter the next day. After reading it, he decides that it is worth all the trouble he has undergone. He even makes up his mind to buy a copy for himself, which means that he must give up eight movies-since it costs 1.80 yuan, one-fifth of his monthly incidentals allowance. The campus bookstore does not have a copy of the book and refuses to order one for Liu because Hsin Hua Bookstore, the sole distributor of Chinese publications, has reported that it is out of print. Liu goes to the district Hsin Hua Bookstore but fails to find a copy there either. The store manager tells him that usually only a few extra copies of a nontextbook title will be ordered so that the bookstore will not be saddled with too many unsold copies-the cost of which must be borne as a loss by the store under the new self-responsibility system. For the same reason, the publisher usually prints only about 10 percent more than the number of copies required to fill the advance orders received through Hsin Hua Bookstore.

Liu then decides to photocopy certain pages of the book. He wants about thirty pages, which, at $30 \mathrm{fen}$ per exposure, would cost him 4.50 yuan (i.e., U.S. \$1.50), while the price of the whole book is only 1.80 yuan. After he has spent a half-hour filling out a copying request and found the copier operator, he is told that the Minolta copier, the only copying machine in the library, is out of order and repair is impossible until the necessary part is shipped from Japan. Liu hence makes up his mind: he will keep the book but report to Circulation that he has lost it. He will be required to pay for its replacement- 1.80 yuan only. The library will not miss this one copy because it has at least ten others. ${ }^{17}$ Keeping the copy, he rationalizes, will not deprive other readers of the title.

Meanwhile, Deputy Director Huang is dusting his office and cleaning the tea set to get his workstation ready for the day. He wonders how much library services would benefit if the time and energy expended on such daily chores by every one of the library staff were spent on library work instead. He will try harder to get approval to institute janitorial services for the library. He also hopes that the day will soon come when the administrator of a unit is no longer required to take care of the daily necessities of his staff like a village elder. He has spent many hours on solving the baby-sitter problem for a staff member.

In sorting the pile of papers on a bookshelf, Huang comes across the floor plan of the Social Sciences Library. The construction of the branch library was supposed to have begun three years ago, but the university administration decided to spend the allocations on building a microwave laboratory and then a computer center. Now that the new university library director is Professor Lai, who has actively involved himself in library matters rather than being a nominal director, perhaps the branch library will get built next year. ${ }^{18}$ Huang has reservations, however, about the twelve reading rooms and a closedstack storage in the new library. Yet it has taken Deputy Director Wu a year to get the blueprint approved by various state, county, city, and district agenciesninety-seven stamps of approval alto- 
". . . professionally trained library workers comprise only 2 percent of China's total library work force."

gether! Any revision of the building plan will require new approval. Besides, Wu has been trained as a librarian by education and experience and is in charge of the daily library operations. He is, therefore, more knowledgeable about matching building space to library functions. Having made up his mind not to suggest any changes, Huang returns the floor plan to the shelf.

Deputy Huang is an associate professor of mathematics, but four years ago he was assigned to the library as a deputy director in charge of personnel, public relations, services, and systems development. Even though he has spent a lot of time learning about library operations and is committed to modernizing and improving library services, he looks upon himself as an administrator rather than a librarian. As a matter of fact, hardly any of the 155 full-time staff members look upon librarianship as a career or profession. Only 25 percent of them have had any higher education, although the 1981 Regulations require that the size of the "professional" cadre in each library be increased gradually to 60 percent.

There are seven members who have graduated from library schools, an impressive figure because professionally trained library workers comprise only 2 percent of China's total library work force. However, despite this good fortune, library services are not as effective as Huang expects. For example, there is a huge backlog of uncataloged science and technology books in English, bought with a loan from World Bank (his library gets about U.S. $\$ 120,000$ per year for five years). Only two of the twenty-five catalogers, both recent library school graduates, have adequate English to separate the books into appropriate areas; neither has enough subject knowledge to classify the books according to the Chinese library

classification scheme. Consequently, professors and graduates complain that the library does not provide enough current foreign publications. The state hopefully will assign more university graduates to university libraries from now on to improve the quality of the library staff as a support unit for science and technology.

Huang has placed the other two recent library school graduates in the reference department, which he set up two years ago as required by the 1981 Regulations. The department consists of four professional cadres occupying a small office. From his visits to American libraries, Huang realizes that an effective reference department must have certain basics: a sizable reading room containing a comprehensive collection of useful sources and a knowledgeable staff with sound communication skills. But there is no space available in the library for even a small reference room.

In order to put together a reference collection, the sources now scattered in the twenty-seven library reading rooms and twelve departmental information rooms would need to be identified, located, and transferred to the reference room. This is a very difficult task, and it will definitely turn the faculty against the library because they are accustomed to having materials for their disciplines grouped together and available to them exclusively. Perhaps he would begin with a small social sciences reference room in the new branch library. He has resigned himself to the reality that it will take a long time for his library to have a full-fledged university reference department. At least he has succeeded in assigning solely professional cadres to the department.

Of the four members, two are responsible for bibliographic instruction, offering a formal two-unit class to science and technology graduate and senior students, as mandated by the National Education Commission. A third member is responsible for answering the questions written down by library users in a "queries book." Most of the questions concern location of materials, literature searches for specific thesis topics, and identification of periodicals from abbreviated titles. The 
fourth member is mainly responsible for doing computerized data searches for the faculty, using the Dialog database tapes at the Academy of Science headquarters. It requires at least two hours of traveling time per trip. How much more productive she would be if she could access the Academy of Science computer, using the IBM PC microcomputer terminal in the library. Again, Huang realizes that this development depends on the state's improvement of the underground cables and telephone system. Very often it takes a half-hour for him to get a telephone line to the other side of town, but when his call gets through the connection is so bad that he can hardly hear the person at the other end of the phone. He envies his American counterparts who apparently get a lot of work done by simply picking up a phone.

Huang ponders whether it would be productive to invite a senior information cadre at the Academy of Science to teach his reference staff how to provide information services. A better solution, he thinks, is to hire a reference expert from overseas, or even from Hong Kong, to spend six months guiding them in this new venture. However, he knows that the university will be very reluctant to spend any of its scarce foreign currency on the library, which is under strict state control. In fact, had it not been for the generosity of IBM, the library would not have been able to obtain foreign currency for the two IBM PC microcomputers in the systems office.

The systems work is making slow progress because of the unavailability of certain necessary items. A simple example is self-adhesive bar code labels. The state has not placed any priority on the manufacturing of adhesive substances. Libraries are still required to expend a lot of human resources on pasting labels on books with poor-quality homemade glue that loses its adhesiveness very shortly. Other obvious examples of what is needed but unavailable are microfilming, printing, and copying equipment. Nevertheless Huang has learned from his American experiences that Chinese libraries need to develop automation systems jointly rather than individually, which, due to the "small but complete" mentality, has been the prevalent mode. Fortunately, the state has established the Committee on Academic Libraries as a national guiding force. Some of the committee's active members, e.g., Huang himself, are fully aware of the importance of networking and have been preaching the standardization of cataloging as a prerequisite for an automated union catalog. Now that the state encourages pro-American approaches in science and technology, the committee has recommended that AACR2 be adapted to Chinese cataloging needs.

The above scenario demonstrates that many of the problems confronting Chinese libraries are caused, and their solutions controlled, by a mix of China's political, social, and economic conditions. As long as the state subscribes to the "iron rice bowl" practice, fosters the "small but complete" concept, insists on convoluted bureaucracy, mandates that managers be responsible for every aspect of their workers' lives, encourages only the profit-loss notion of the self-responsibility system, and concentrates only on the "four modernizations" to the neglect of other necessities, Chinese libraries will find it very difficult to achieve modernization. The 1981 Regulations may have established sound goals and reasonable standards for academic libraries, but the state must also provide means for the libraries to achieve them. Until the situation improves, Chinese university libraries will remain a challenge to library users.

\section{REFERENCES AND NOTES}

1. Ching-chih Chen, "Education and Training in Information Science in the People's Republic of China," Bulletin of the American Society for Information Science 6:16-18 (Apr. 1980). 
2. K.P. Broadbent, "The Modernization of Information Services in the People's Republic of China," Journal of Information Science 3:227-33 (Nov. 1981).

3. Lee-hsia (Hsu) Ting, "Chinese Libraries during and after the Cultural Revolution," Journal of Library History 14:428-29 (Spring 1981).

4. James Chan, "Selling Books in China," Publishers Weekly, Aug. 8, 1986, p.23-26.

5. Maureen Pastine, "An International Library Exchange in China," College \& Research Libraries News 47:398 (June 1986).

6. Elizabeth Wood went to China to visit her brother, a missionary. The visit lasted for more than thirty years, until her death in 1931 . She made several return trips to the states to raise money for setting up the public library and the library school and to train herself for the library profession by attending Pratt Institute and Simmons College. For detailed information, see John H. Winkelman, "Mary Elizabeth Wood (1861-1931)," Journal of Library and Information Science 8:62-76 (Apr. 1982).

7. China Exchange News 12:1-20 (Sept. 1984).

8. Yixian Guan, "Views on Improving China's Library Professional Education" (in Chinese), Bulletin of the China Society of Library Science 4:82 (Dec. 1982).

9. Xingyun Luo, "Libraries and Information Services in China," Journal of Information Science 6:21-31 (Mar. 1983).

10. The author had interesting and at times excited discussions with some information science instructors who had themselves been information scientists. They seemed to consider their functions similar to those performed by researchers in such think tanks as the Rand Corporation. The author was permitted to go to several classes in China's leading library schools to get a glimpse of their information science classes. In one class (lasting 2.5 hours) the instructor spent about an hour on explaining brainstorming. According to some recent library school graduates working in the libraries visited by the author, they spent much class time on the debate over whether library science and information science should be integrated. Apparently the title information scientist enjoys far more prestige than librarian.

11. Due to the peculiarities of the Chinese written language and to the different filing systems existing side by side, the author or title catalog is also not easy to use.

12. Between August and November 1985, the author took a user survey at eight key Chinese university libraries in Beijing, Chengdu, Chongqing, Wuhan, Shanghai, and Guangzhou. About 500 questionnaires were hand-delivered to individual undergraduate and graduate students and professors using the library; about 450 were collected, again by the author personally. In the near future, when all the data have been tabulated and analyzed, a report will be issued.

13. Zhi-gang Ding, "A Message to the New Bulletin," Bulletin of the China Society of Library Science 1:7 (1979), trans. and quoted by Lee-hsia (Hsu) Ting, "Chinese Libraries," p.425.

14. The characters are a mixture of the people with whom the author had come into contact, but the incidents are actual happenings.

15. Many Chinese suffer from this problematic state of mind-the mutually exclusive compartmentalization of knowledge. Annie Dillard, in her book, Encounters with Chinese Writers (Middletown, Conn.: Wesleyan Univ. Pr., 1984) p.45-46, illustrates this succinctly in the episode about her visit to China's National Library.

16. "In late 1983, a three member team of U.S. librarians . . . visited 12 . . . (key Chinese) libraries and found that Chinese librarians tend to look upon computers as a panacea for their administrative and cataloging problems," reports Chi Wang, "An Overview of Libraries in the People's Republic of China," China Exchange News 12:4 (Sept. 1984).

17. The average duplication rate of Chinese publications in university libraries is now $10-12$ copies. Titles that are used as supplementary texts usually have 30 to 50 duplicate copies; some even have 50 to 100 copies. When a university library gives a figure for its collection size, divide that figure by ten to get a more accurate estimate of its number of titles.

18. The 1981 Regulations require that university library directors first hold positions as full professors. In most libraries, the "directors" are, therefore, directors in name only, while the administration is actually executed by deputy directors (usually two to three per library). 